\title{
La aterradora luz helada de una certeza
}

\author{
ANALÍA GERBAUDO Universidad Nacional del Litoral - CONICET, Argentina / \\ agerbaudo@fhuc.unl.edu.ar/analia.gerbaudo@conicet.gov.ar
}

\begin{abstract}
Tener un amigo, conservarlo. Seguirle con la mirada. Cuando él ya no está aquí, seguir viéndole y esforzarse en buscarle, escucharle o leerle, cuando uno sabe que no le verá más, eso es llorar.

Tener un amigo, mirarle, seguirle con la mirada, admirarle como amigo, consiste en saber, de una manera intensa, y afligida por adelantado, siempre insistente, y cada vez más presente, que uno de los dos fatalmente verá morir al otro.

Jacques Derrida, «El sabor de las lágrimas»
\end{abstract}

«Lo que experimento ante la muerte de cualquiera, y de una manera más vehemente e incontrovertible ante la muerte de algún pariente o un amigo, de tal o cual persona querida (...) es lo siguiente: la muerte del otro, no únicamente pero sí principalmente si se le ama, no anuncia una ausencia, una desaparición, el final de tal o cual vida, es decir, de la posibilidad que tiene un mundo (siempre único) de aparecer a tal vivo. La muerte proclama cada vez el final del mundo en su totalidad, el final de todo mundo posible, y cada vez el final del mundo como totalidad única, por lo tanto irremplazable y por lo tanto infinita» (Derrida, 2005:11). Así arranca Cada vez única, el fin del mundo de Jacques Derrida. Se trata de un texto singular que bien podríamos considerar anticipado por otros dos: el primero, The Work of Mourning, publicado en 2001 por Michael Naas y Pascale-Anne Brault quienes incentivan a Derrida a compilar los trabajos que había escrito a propósito de la partida de sus amigos. El segundo, la versión francesa del anterior, Chaque fois unique, la fin du monde, datada en 2003. El tercero, la traducción al español que aquí consultamos, bajo el cuidado de Manuel Arranz, publicada en 2005. Nuestro comentario tal vez podrá anticiparse: el 8 de octubre de 2004, mientras Arranz trabajaba en su traducción, Derrida moría en París. Además de su posfacio, «Hasta siempre», Arranz anexa un ensayo de Jean-Luc Nancy, «Derrida da capo».

Mientras colgábamos el número anterior de El taco... en la Web, fuimos sacudidos por la muerte de un amigo a quien esta revista, entre tantos otros espacios institucionales, le debe su existencia: Claudio Lizárraga. En ese momento, el texto de Derrida se impuso por más de un motivo.

En la inmediatez del dolor, contra el que poco pueden los abrazos y las lágrimas, la potencia

Para citar este artículo: Gerbaudo, A. (2019). La aterradora luz helada de una certeza. El taco en la brea, 10 (junio-noviembre), 2-4. Santa Fe, Argentina: UNL. DOI: 10.14409/tb.vii1o.8680 
metonímica de la escritura de Derrida (junto a las de Santiago Venturini, Alberto Giordano y Javier Gasparri, entre otras) irrumpía al modo de un llamado, de su «ven»: «"Dios” quiere decir: la muerte puede poner fin a un mundo, pero no significa el fin del mundo. Un mundo siempre puede sobrevivir a otro. Hay más de un mundo. Más de un mundo posible. Esto es lo que nos gustaría creer, por poco que creamos o creamos creer en "Dios". Pero la muerte, la muerte misma, si es que hay algo a lo que pueda llamarse así, no deja lugar, ni la menor oportunidad, ni al recambio ni a la supervivencia del solo y único mundo, del "solo y único" que hace de cada ser vivo (animal, humano o divino), un ser vivo solo y único» (2005:13). Cada vez que una vida termina, es el mundo que se definía junto con ese que ya no está el que termina, para siempre: «el final del mundo mismo, del único mundo que existe, cada vez. Singularmente. Irreversiblemente. Para el otro y de una extraña manera para el provisional superviviente que soporta la imposible experiencia. Esto es lo que quiere decir "el mundo". Un significado que sólo le confiere eso que llamamos "la muerte"» (11).

Frente a la falta de consuelo místico, la textualización del dolor vía la escritura por quienes ya habían pasado por la experiencia de perder a un amigo se presentaba como una tabla de salvataje. Y en particular la de Derrida en la que un texto de duelo envía a otros que hacen sentido para nosotros, aquí y ahora. El pasaje en el que Derrida vuelve, mientras escribe su despedida a Roland Barthes, sobre "La fotografía del Jardín de invierno», la única que Barthes no incluye en $L a$ Chambre claire y que retrata a su madre de niña, da cuenta de la relación entre metonimia y posibilidad de tocar a quien lee, de llegar a quien lee, de con-moverlo:

La Fotografía del Jardín de Invierno, que no enseña ni oculta, pero de la que habla, es el punctum de todo el libro. La huella de esta herida única no es visible en ninguna parte como tal, pero su claridad inubicable (la claridad de los ojos de su madre) irradia en todo el estudio. Hace de este libro un acontecimiento insustituible. Y sin embargo, sólo una fuerza metonímica puede garantizar todavía cierta generalidad del discurso, ofrecerla al análisis, proponer sus conceptos para una utilización casi instrumental. Porque de otro modo, ¿por qué razón, si no la conocemos, nos iba a conmover lo que dice de su madre, que no fue únicamente la Madre, ni una madre, sino solamente aquella que una vez fue, y de la que una foto, tomada «aquel día...»? ¿Cómo nos iba a resultar desgarrador todo esto, si no hubiera una fuerza metonímica en el fondo, que no hay que confundir con un fácil recurso del proceso de identificación? (2005:80)

Derrida «solicita», vía sus ya clásicos «bucles extraños», las derivas ético-políticas de estas escrituras de duelo mientras las produce. Este movimiento, datado, incluye no sólo a las existentes entonces sino también a las por-venir, es decir, esta misma que ustedes están leyendo ahora: los riesgos de caer tanto en el uso, personal y político, como en el regodeo narcisista de quien escribe, acechan.

«Sé perfectamente que Louis no me puede oír» (130), se dice Derrida a propósito de Althusser, apenas fallecido. «Él sólo me oye dentro de mí, dentro de nosotros (...) que sólo podemos ser nosotros mismos a través de la resonancia en nosotros del otro)» (130). Entonces, bien valdría preguntarse, ¿para qué escribir o para quiénes, si el amigo ausente ya no puede oírnos?

Si aceptamos, junto a Derrida, que «el amigo ya sólo puede estar en nosotros» (2005:170), necesitamos escribir, básicamente, para hacer archivo. Única forma de traer o devolver algo a la vida, aunque ese devolver no sea más que una huella de una práctica, de un modo de hacer que, en este caso, por tener una inscripción institucional, fantaseamos con que deje marca. Si el otro ya sólo 
puede estar en nosotros, entonces, ¿cómo no escribir, cómo no hablar, cómo no enseñar algo de lo transferido a pesar de la mínima, escasa ilusión, de que algo de todo ello reste, de que al menos alguna de las imágenes del otro en nosotros, reste?:

Cuando decimos «en nosotros», y cuando hablamos tan fácilmente y tan dolorosamente de dentro y de fuera, estamos nombrando el espacio, estamos hablando de una visibilidad del cuerpo, de una geometría de las miradas, de una orientación de las perspectivas. Hablamos de imágenes. Aquello que está en nosotros parece reducirse a imágenes, que pueden ser recuerdos o monumentos, pero en cualquier caso están reducidas a una memoria formada por escenas visibles que no son más que imágenes puesto que el otro, del que son la imagen, sólo aparece en ellas, precisamente, como el desaparecido, aquel que vemos en imagen o en el recuerdo, él, de quien hablamos, al que citamos, al que intentamos devolver o ceder la palabra, él ya no está, ya no está aquí, ni en ninguna parte. Y nada puede evitar la aterradora luz helada de esta certeza. Como si el respeto de esta certeza fuera todavía una deuda, la última, que tenemos con el amigo. (2005:170)

Entre esas imágenes del otro en nosotros, algunas pocas. Las fundamentales, tal vez (o más bien, tal vez para mí, en singular), podrían resumirse en dos palabras: hospitalidad y alegría. Esa conjunción era su marca. Así construía. Ese era su modo de tender lazos en y entre las instituciones.

A Claudio le gustaba un cruce hereje que solía escucharme entre el «hacer cosas con palabras» de John Austin con el «una palabra tuya bastará para sanarme» de los Evangelios y «confianzas» de Juan Gelman. Nunca hablamos de Cada vez única, el fin del mundo. No sé si le hubiera interesado. Demasiado desencanto y arrojo y soledad en un mundo sin Dios, tal vez. Sin embargo creo que valoraría que, a pesar del desencanto y del arrojo y de la soledad en el tránsito por este mundo-sinDios, sigamos construyendo (escribo en plural, desde aquí hasta el final, en nombre de uno de los colectivos de «letras» con los que trabajaba: ese que formamos con Germán Prósperi e Ivana Tosti).

Desde estos atravesamientos, o más bien, por estos atravesamientos (entre otros), leemos la literatura y la teoría que leemos, porque sin esa literatura y sin esa teoría la vida que incluye al trabajo sería sencillamente insoportable. Pensar, escribir, enseñar y/o editar literatura no están, nunca estuvieron, sólo como parte del trabajo (como si ese trabajo de pensar, escribir, enseñar y/o editar fuera algo que aleja de la vida, como si no la habitara). Desde estos atravesamientos, con estas pocas fantasías de orden «nano», también hacemos esta revista. 